\title{
CHROMOSOME VARIATION IN TULBAGHIA
}

\author{
CANIO G. VOSA
}

Botany School, Oxford

Received ro.x.65

Tulbaghia is a genus of about 20 species all from South Africa. In general morphology, and odour, they resemble Allium; the flowers are very variable in form and colour and are characterised by a corona inserted at the throat of the perianth-tube. Only a few species have been examined cytologically.

\section{MATERIALS AND METHODS}

The sources of the material are indicated in table I. Root-tips were pretreated in 0.05 per cent. aqueous solution of colchicine for 4 hours for the diploids, and up to six hours for the polyploid species.

TABLE I

Chromosome counts and sources of Tulbaghia species

\begin{tabular}{|c|c|c|c|c|}
\hline \multicolumn{3}{|c|}{ Species } & $2 n=$ & Source \\
\hline $\begin{array}{l}4 x \\
6 x\end{array}$ & $\begin{array}{l}\text { acutiloba } \\
\text { pulchella } \\
\text { leucantha } \\
\text { Dregeana } \\
\text { natalensis } \\
\text { violacea } \\
\text { alliacea } \\
\text { capensis }\end{array}$ & $\begin{array}{l}\text { Harv.* } \\
\text { Barnes* } \\
\text { Baker* } \\
\text { Kunth. } \\
\text { Baker } \\
\text { Harv. } \\
\text { L. } \\
\text { L. }\end{array}$ & $\begin{array}{l}12 \\
12 \\
12 \\
12 \\
12 \\
12 \\
24 \\
36\end{array}$ & $\begin{array}{l}\text { Warmbad (South-west Africa) } \\
\text { Letaba (Pietermaritzburg, Transvaal) (+) } \\
\text { Warmbad (South-west Africa) } \\
\text { Oxford Botanic Garden ( }+ \text { ) and Kew Gardens } \\
\text { Impendhle (Natal) } \\
\text { Oxford Botanic Garden and Kirstenbosch Botanic } \\
\text { Botanic Garden (+) } \\
\text { Estcourt (Natal) } \\
\text { Kirstenbosch Botanic Garden }\end{array}$ \\
\hline
\end{tabular}

* H-segments.

$(+)$ described by Dyer (1963).

Anthers at the proper stage of development, usually before the colouring of the perianth, were squashed in I. 5 per cent. acetic-orcein (Vosa, I96I) without any pretreatment or fixation. Owing to the fragility of the p.m.c.'s, the slide was left for six or more hours and often overnight prior to pressing between filter paper. All the preparations were made permanent following the schedule suggested by Darlington and La Cour ( 1963 ).

All the species start flowering in early spring except $\mathcal{T}$. pulchella which may flower either early in the spring or in the autumn. All the cytological preparations for the study of meiosis were made at about I I a.m., when the greenhouse temperature reached about $20^{\circ} \mathrm{C}$.

Chromosome complement and morphology. In all the species so far studied the basic chromosome number is six and the chromosomes are large with mostly median or submedian centromeres. In figs. 2, 3 and 4 chromosomes have been arranged and numbered in order 
according to their length and type. There are four types of nucleolar chromosomes (fig. $\mathrm{r}$ ). In type A which is present in $T$. violacea, $T$. pulchella and $T$. acutiloba, the nucleolar constriction is in the long arm of chromosome 6 . In the last species there are two types of nucleolar chromosome: type A and type B which consists of chromosome 2 with nucleolar constriction in its short arm. The other two types, $\mathrm{C}$ and $\mathrm{D}$, have a sub-terminal centromere and nucleolar attachment which is terminal on the short arm. Type $\mathrm{C}$ is found only in the hexaploid T. capensis where the nucleolar attachment is terminal on the short arm of chromosome 2 and type $\mathrm{D}$, which is found in T. Dregeana, $T$.

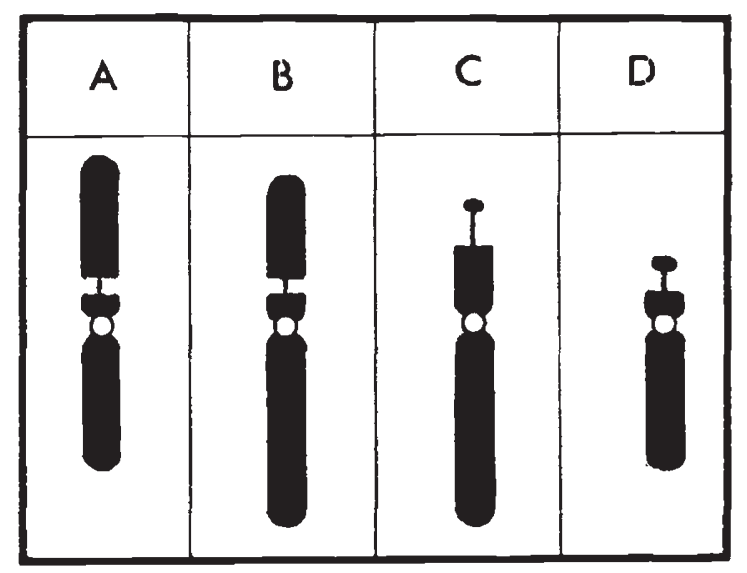

FIG. 1.-Nucleolar chromosome types in Tulbaghia $(\times 2100)$.

natalensis and $T$. leucantha, where the nucleolar attachment is terminal on the short arms of chromosome 6, which is the shortest of the complement. No detectable heterozygosity was noted in types A and B but types $\mathrm{C}$ and $\mathrm{D}$ showed considerable variation in the size of the satellite attached to the nucleolar thread, and all the plants studied were heterozygous for these particular chromosome types.

The chromosome complements of Tulbaghia violacea and T. Dregeana (as T. alliacea) and of a clone of T. pulchella have been described in detail by Dyer ( 1963$)$. The haploid chromosome length of all the species studied has been summarised in table 2 .

There is a variation in the total chromosome length which ranges from $96 \cdot 5 \mu$ in T. alliacea to $56 \cdot I \mu$ in T. pulchella. It is interesting to note that the tetraploid $T$. alliacea possesses the largest chromosomes. This is a departure from the usual situation where the polyploid species have smaller chromosomes than the diploids. The other polyploid T. capensis $(6 x=36)$ does not show a difference in chromosome size; in fact the chromosomes of this species are very near average in total length.

In the eight Tulbaghia species studied, including the three possessing $\mathrm{H}$-segments, the main variations in the six basic chromosome types, apart from differences in chromosome length and the distribution of 
heterochromatin, are found in chromosome type 2 and 6 (figs. 2 and 3, table 2).

Heterochromatin. Besides T. pulchella already studied by Dyer (1963), T. acutiloba and T. leucantha (fig. 3) were found to possess chilling reactions of heterochromatic segments $(\mathrm{H})$.

TABLE 2

The length in $\mu$ of the haploid chromosome complements of 8 species of Tulbaghia. Measurements based on 5 diploid cells in each species

\begin{tabular}{|c|c|c|c|c|c|c|c|c|}
\hline & \multirow{2}{*}{ Species } & \multicolumn{6}{|c|}{ Chromosome type } & \multirow{3}{*}{$\begin{array}{c}\begin{array}{c}\text { Total } \\
\text { lengths }\end{array} \\
79.9\end{array}$} \\
\hline & & 1 & 2 & 3 & 4 & 5 & 6 & \\
\hline \multirow[t]{6}{*}{$2 x$} & acutiloba $(+)$ & $19 \cdot 2$ & $16 \cdot 0$ & $12 \cdot 2$ & $10 \cdot 7$ & $9 \cdot 8$ & $12 \cdot 0$ & \\
\hline & pulchella $(t)$ & $11 \cdot 4$ & $10 \cdot 6$ & $9 \cdot 1$ & $8 \cdot 4$ & $7 \cdot 7$ & $8 \cdot 9$ & $56 \cdot 1$ \\
\hline & leucantha $(+)$ & $13 \cdot 2$ & 13.0 & $12 \cdot 0$ & $10 \cdot 0$ & $8 \cdot 8$ & $9 \cdot 9-8 \cdot 8$ & $65 \cdot 9$ \\
\hline & Dregeana & $14 \cdot 2$ & $13 \cdot 9$ & $10 \cdot 3$ & $9 \cdot 7$ & $8 \cdot 3$ & $6 \cdot 5$ & $62 \cdot 9$ \\
\hline & natalensis & 14.4 & 13.8 & 10.8 & $10 \cdot 3$ & $9 \cdot 8$ & $7 \cdot 6$ & $66 \cdot 7$ \\
\hline & violacea & $14 \cdot 5$ & $11 \cdot 5$ & $I I \cdot 3$ & $10 \cdot 2$ & $9 \cdot 9$ & $9^{\cdot 8}$ & $67 \cdot 2$ \\
\hline $4^{x}$ & alliacea & $20 \cdot 7$ & $16 \cdot 9$ & $15 \cdot 6$ & $14 \cdot 6$ & 13.4 & $15 \cdot 3$ & $96 \cdot 5$ \\
\hline $6 x$ & capensis & $14 \cdot 2$ & $12 \cdot 8$ & 11.8 & $10 \cdot 6$ & $10 \cdot 1$ & $9 \cdot 2$ & $68 \cdot 7$ \\
\hline
\end{tabular}

(+) H-segments.

In T. acutiloba the $\mathrm{H}$-segments are all terminal and all the plants studied show heterozygosity in the position and size of the segments.

The $\mathrm{H}$-segments of $T$. leucantha are all intercalary with the exception of chromosome 6 where the arm distal to the nucleolar constriction is wholly heterochromatic. This species, of which unfortunately only one plant was available, is very similar to $T$. Dregeana. The only differences detectable in the two species are the type of growth which is spreading, somewhat creeping in $\mathcal{T}$. Dregeana and erect and clumpforming in $T$. leucantha, where the flowers are slightly smaller and the leaves narrower. The two species are, however, easily separated by their chromosome morphology and only $T$. leucantha possesses $\mathrm{H}$ segments. 
This species resembles Fritillaria, Trillium kamtschaticum, T. erectum and Cestrum (Dyer, 1963) in two respects:

(i) the distribution of heterochromatin is mainly close to the centromere corresponding to the region of chiasma localisation;
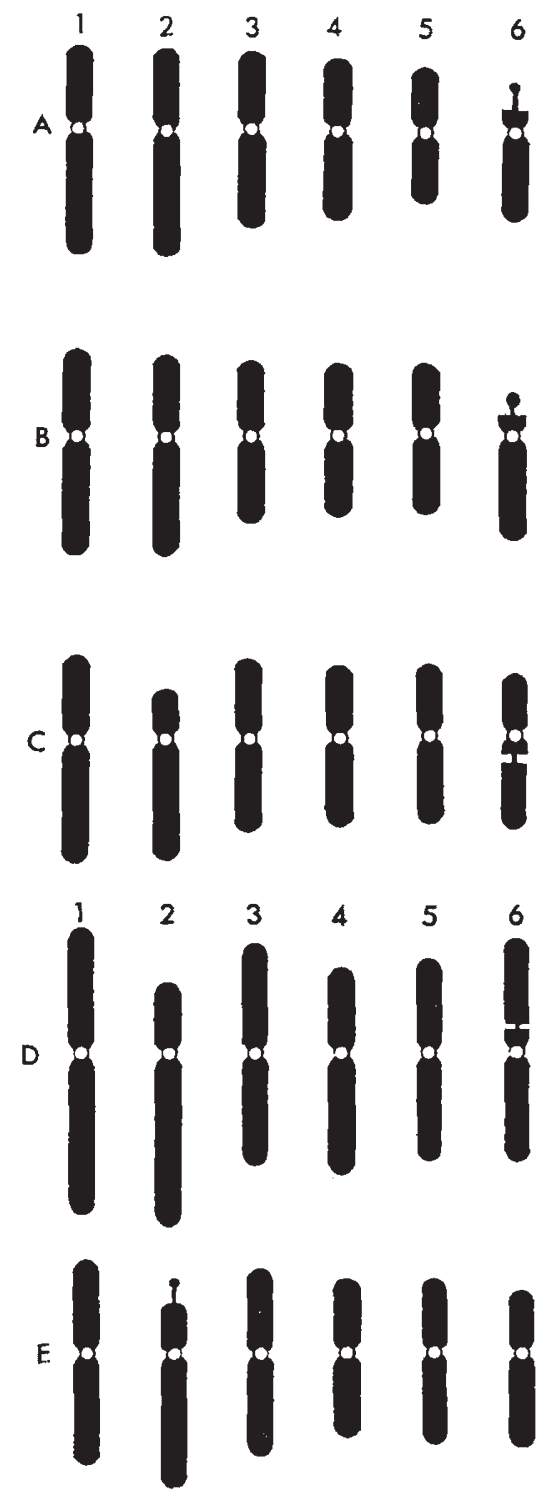

FIG. 2. - The haploid complement of five species of Tulbaghia without H-segments ( $\times$ r 400).

$$
\begin{array}{cc}
\text { A-T. Dregeana. } & \text { B-T. natalensis. } \\
\text { C-T. violacea. } & \text { D-T. alliacea. } \\
\text { E-T. capensis. }
\end{array}
$$

(ii) the $\mathrm{H}$-segments are broken into small pieces interrupted by euchromatic regions and it seems that the proximally localised crossing-over may have caused rearrangements in the $\mathrm{H}$-pattern. 

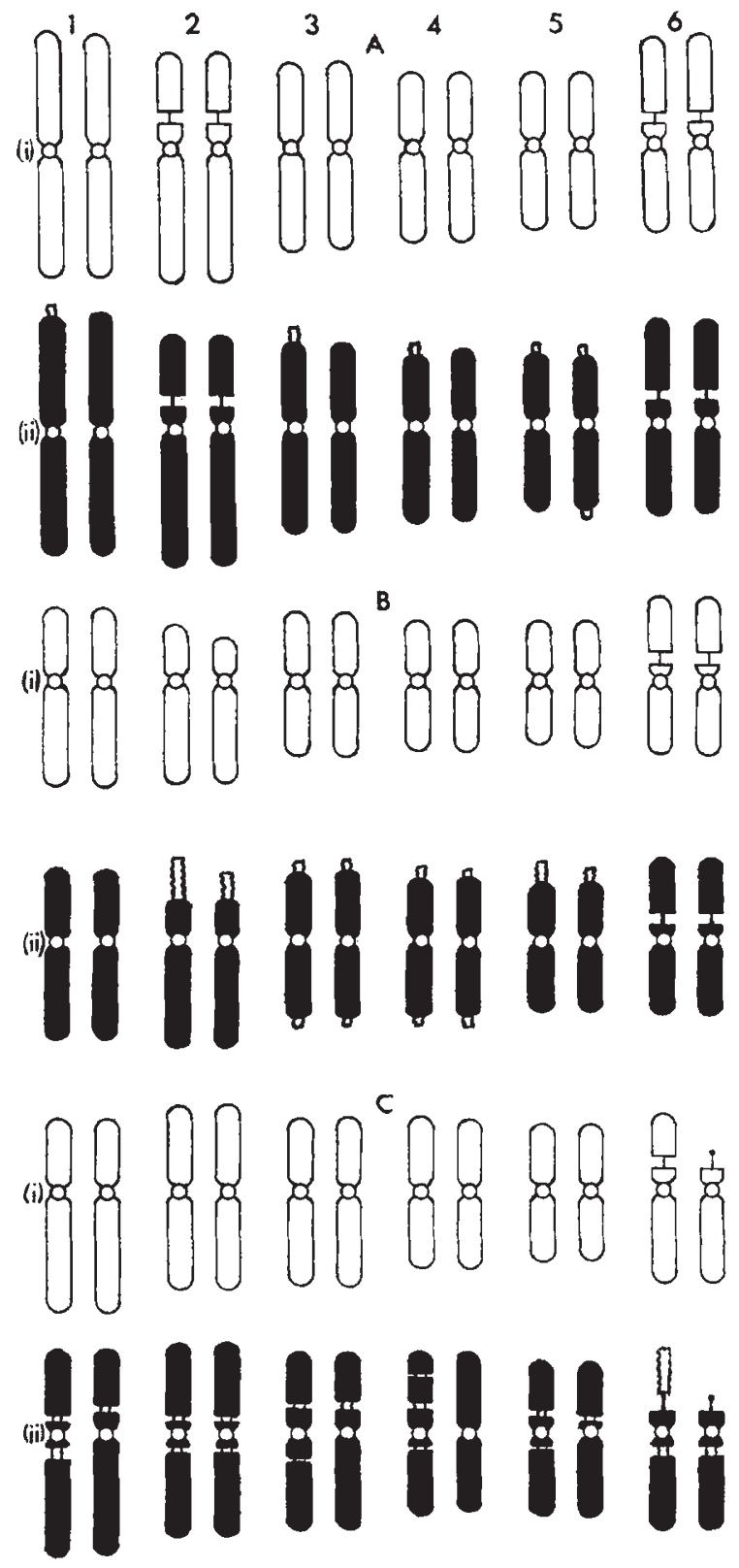

Fig. 3.-The chromosome complements of three species of Tulbaghia with H-segments. ( $\times 1400)$.

$$
\text { A-T. acutiloba. } \quad \mathrm{B}-T \text {. pulchella. }
$$

(i) At normal temperature $\left(20^{\circ}\right.$ C.) pretreated for four hours with 0.05 per cent. colchicine.

(ii) Chilled for $9^{6}$ hours at $4^{n} \mathrm{C}$. 
The pattern of heterochromatin in the chromosomes of the clone of $T$. pulchella used in this study is slightly different from that in the plant described by Dyer ( 1963 ).

The chromosome complements of the three Tulbaghia species possessing $\mathrm{H}$-segments vary morphologically from each other (fig. 3). This situation differs from that found in Trillium where the five basic chromosomes seem to correspond in all species (Darlington and Shaw, 1959). This suggests that large structural rearrangements of the chromosomes occurred in Tulbaghia during speciation.

TABLE 3

Chiasma frequency and distribution at MI in six diploid species of Tulbaghia

\begin{tabular}{|c|c|c|c|c|c|}
\hline Species & $\begin{array}{c}x t a \\
\text { per cell }\end{array}$ & \multicolumn{2}{|c|}{ Chiasma localisation } & \multicolumn{1}{|c|}{$\begin{array}{c}\text { Total } \\
\text { no. of } \\
\text { cells }\end{array}$} \\
\hline acutiloba (H) . & 14.4 & 11.60 & 2.40 & 0.40 & 25 \\
\hline pulchella (H) . & 12.2 & 8.80 & 0.84 & 2.56 & 25 \\
\hline leucantha (H) . & 12.3 & 10.60 & 0.90 & 0.80 & 18 \\
\hline Dregeana & 13.2 & 8.10 & 2.30 & 2.80 & 30 \\
\hline natalensis & 15.9 & 11.00 & 3.20 & 1.70 & 20 \\
\hline violacea . & 11.1 & 8.90 & 0.70 & 1.50 & 30 \\
\hline
\end{tabular}

The proportion of heterochromatin in Tulbaghia varies from $3 \cdot 1$ to 12.7 per cent. of the total chromosome length. In $\mathcal{T}$. acutiloba, where eight plants were available, the H-pattern is very uniform and the proportion of heterochromatin varies from 3.1 to 3.5 per cent. This uniformity is probably due to the fact that the eight plants were obtained from seeds collected from the wild, possibly from a related plant population. The percentage of heterochromatin has been calculated from linear measurements of the chromosomes at mitotic metaphase, after chilling for 96 hours at $\pm 4^{\circ} \mathrm{C}$.

Meiosis. All the Tulbaghia species studied, including the polyploids T. alliacea $\left.4^{x}=24\right)$ and $T$. capensis $\left(6 x=3^{6}\right)$ show strong proximal chiasma localisation (plates I and II). The chiasma frequency and distribution in the six diploid species are summarised in table 3.

In Tulbaghia as in Paris (Darlington, 1941) the same type of proximal localisation is present in all the species with no relation to the position of the H-segments or to polyploidy. It seems, therefore, 


\section{Plate $I$}

The meiotic chromosomes of three species of Tulbaghia without $H$ segments:

I. T, Dregeana: 15 xta (8 proximal).*

2. T. natalensis: 17 xta (12 proximal).*

3. T. violacea: $17 \times t a$ ( 12 proximal).

$(\times 2200)$

* Nucleolar bivalent (6) heterozygous for distal deficiency. 

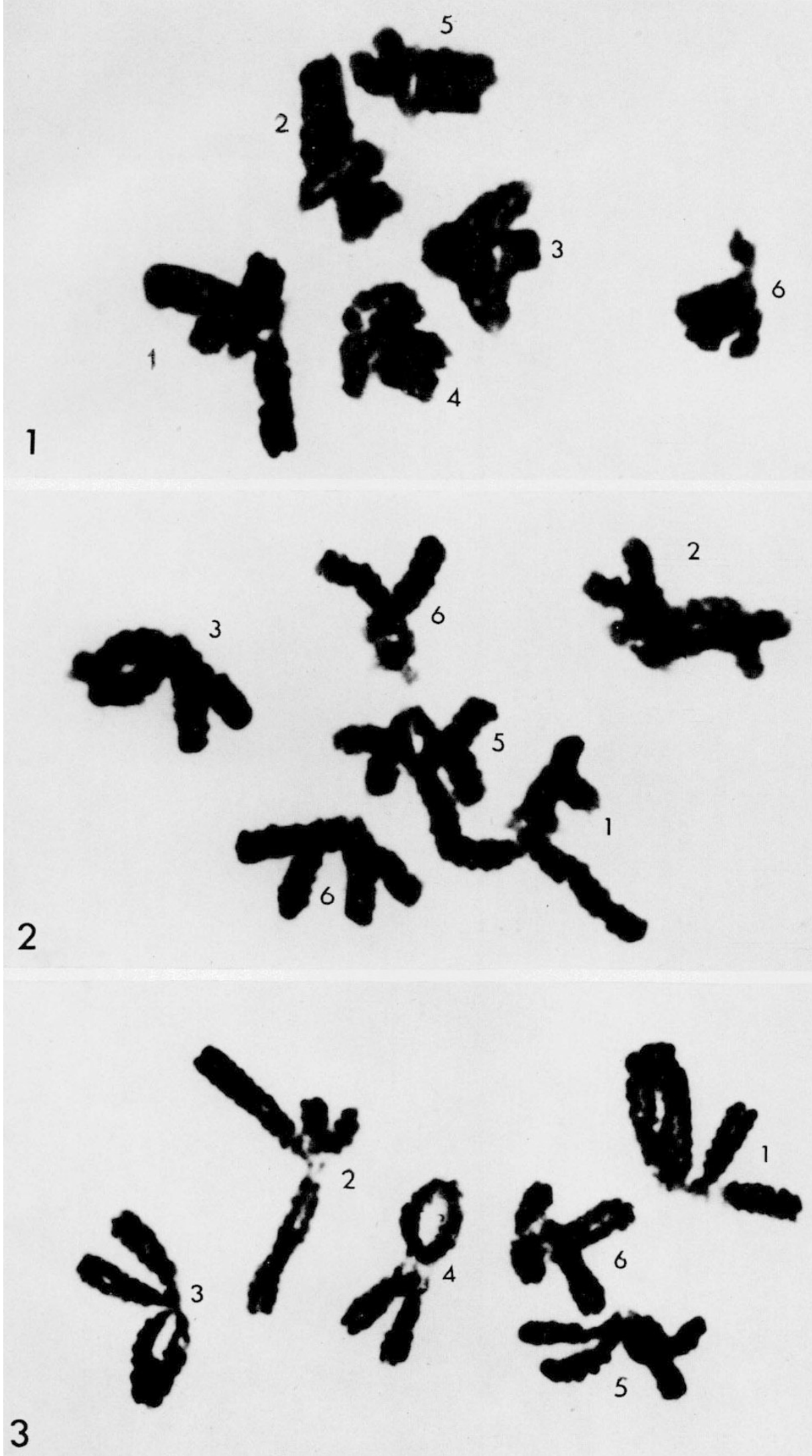


\section{Plate II}

The meiotic chromosomes of three species of Tulbaghia with $H$-segments:

1. T. acutiloba: $19 x t a$ ( 12 proximal). In bivalent 1 and 2 the long arms overlap.

2. T. leucantha: $14 \times t a$ (I 1 proximal).*

3. T. fragrans: $19 \times t a$ (Io proximal)

$$
(\times 2200) \text {. }
$$

* Nucleolar bivalent (6) heterozygous for distal deficiency. 


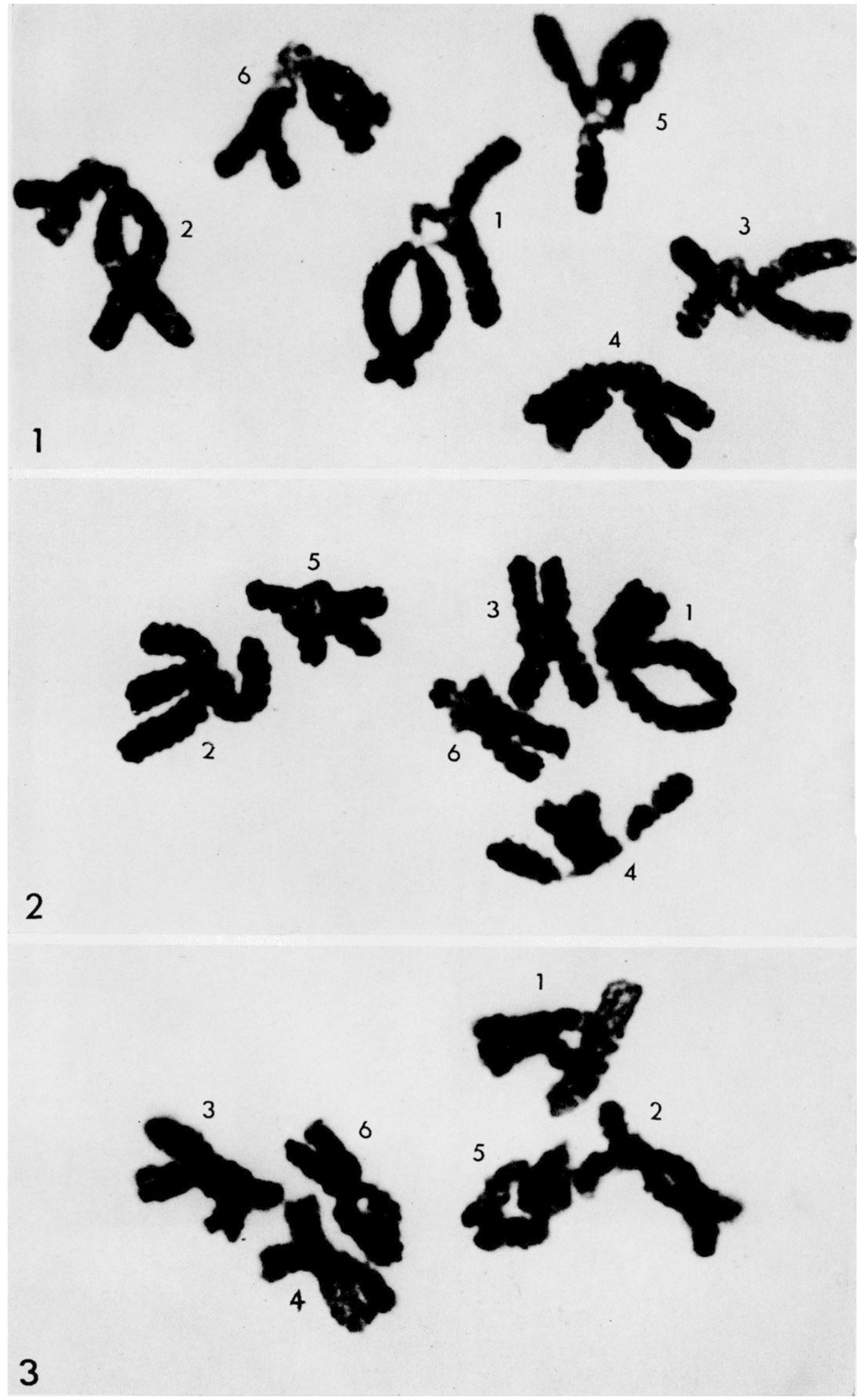


that localisation of crossing-over is a characteristic trait of all the species of Tulbaghia and it has been maintained all through the evolution and speciation of the genus.

The situation in Tulbaghia is very similar to that in the Japanese species of Trillium where there are also proximally localised chiasmata.

In Tulbaghia however the reduction of crossing-over in the distal regions seems to have favoured the development of differential segments segregating as units. For it is surely to be connected with the observation of heterozygosity for deficiencies in the distal ends found in the nucleolar chromosomes of four of the eight species studied.

\section{SUMMARY}

The basic chromosome number of eight species of Tulbaghia is six. Three species were found to possess chillable $\mathrm{H}$-segments which are localised mainly near the centromere in $T$. leucantha and distally in T. pulchella and T. acutiloba. T. alliacea and T. capensis are polyploids, $4 x=24$ and $6 x=3^{6}$ respectively. All the species, including the polyploids, show strong proximal localisation of chiasmata. In $T$. leucantha, $\mathcal{T}$. natalensis, $\mathcal{T}$. Dregeana and $\mathcal{T}$. capensis the nucleolar chromosomes are heterozygous for a distal deficiency.

Acknowledgments. - I wish to thank Professor C. D. Darlington for his helpful advice and criticism during the course of this work. For providing me with the indispensible material necessary for this study I am most grateful to Professor H. B. Rycroft, Director of the Botanic Garden, Kirstenbosch, Dr L. E. Codd and Dr B. de Winter from the Department of Agricultural Services, Pretoria; Dr A. A. Moffet and Dr P. I. Gildenhuys of the Wattle Research Institute, Pietermaritzburg, Natal.

I wish to thank Dr K. Jones, Mr A. A. Bullock, Mr G. E. Hubbard and Mr M. S. Sands of the Royal Botanic Gardens, Kew, for their help in the identification of some of the Tulbaghia species.

\section{REFERENCES}

DARLington, C. D., AND LA COUR, L. F. I963. The Handling of Chromosomes. Allen \& Unwin, London.

DARLington, C. D., AND SHAW, G. W. I 959 . Parallel polymorphism in the heterochromatin of Trillium species. Heredity, 13, 89-1 $2 \mathrm{I}$.

DARLington, C. D. 194I. Polyploidy, crossing over, and heterochromatin in Paris. Ann. Bot., 5, 203-2 I6.

DYER, A. F. 1963. Allocyclic segments and structural heterozygosity. Chromosoma (Berl.), $13,545-576$.

vosA, c. G. I96I. A modified aceto-orcein method for Pollen Mother Cells. Caryologia, 14, 107-1 I0.

\section{NOTE ADDED IN PROOF}

Whitaker and Florey (1965) have published karyograms of I species of Tulbaghia including two tetraploids. They list $T$. alliacea $2 n=12$ which probably corresponds to my $T$. acutiloba $2 n=12$, and is chromosomally distinct from both $T$. ludwigiana $4^{n}=24$ and $T$. alliacea $4^{n}=24$ which have the same karyotype. 
Of the two forms of $T$. leucantha, the diploid $(2 n=\mathrm{I} 2)$, is heterozygous for the nuclear chromosome. It may belong to the same clone of $T$. leucantha as I used.

\section{Reference}

WhitAKer, H. M., AND florey, W. S. 1965. Chromosome number and morphology in Tulbaghia. Plant Life (Amaryllis year book), 2I, 67-8I. 